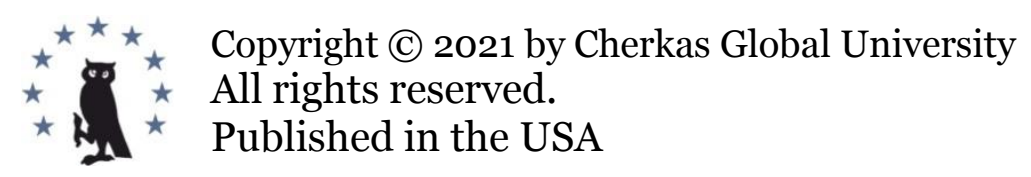

European Journal of Contemporary Education

E-ISSN 2305-6746

2021. 10(4): 912-923

DOI: 10.13187/ejced.2021.4.912

https://ejce.cherkasgu.press

IMPORTANT NOTICE! Any copying, reproduction, distribution, republication (in whole or in part), or otherwise commercial use of this work in violation of the author(s) rights will be prosecuted in accordance with international law. The use of hyperlinks to the work will not be considered copyright infringement.

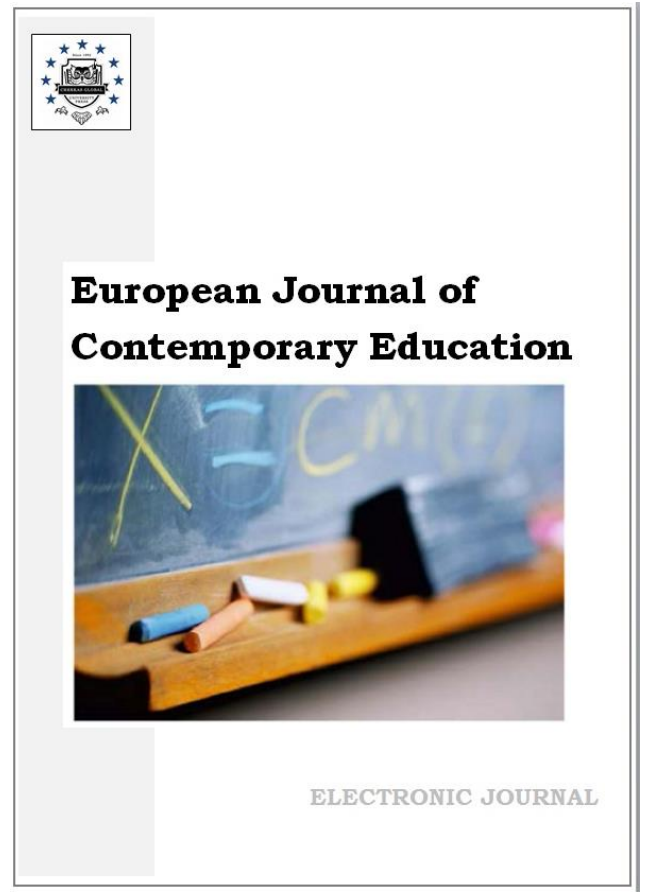

\title{
Issues of Training Specialists for the Market of State (Municipal) Procurement in Russia
}

Svetlana S. Gorokhova a, Anna V. Popova a, *, Angela S. Voskovskaya a , Elena Yu. Barakina a

a Financial University under the Government of the Russian Federation, Russian Federation

\begin{abstract}
Significant efforts are being made in the Russian Federation to improve the quality of education at all levels of the education system, to form a complete list of professional standards covering the entire spectrum of available professions. Considering that the market for public procurement and procurement by certain types of legal entities is one of the most important segments of the Russian economy, the purpose of the research is to study the level and focus of the education system, professional training of employees in this area, as well as educational opportunities of the environment to provide the relevant areas of training specialists for higher education and secondary vocational education that correspond to the specifics of procurement activities. Based on the analysis of legal documents, scientific literature and the survey conducted by the authors of the article among a sufficient number of respondents, the following key conclusions were made. Despite the fact that today in Russia there is a professional standard "Public procurement specialist" that establishes the requirements for the level of education for this group of employees, however, which direction of training for such a specialist to choose is not indicated. In the modern system of higher education of the Russian Federation there are no special areas of training "Public procurement specialist" or "Tender specialist". The authors of the article believe that it is necessary to introduce into the system of education a separate direction for training specialists in this area of public administration.
\end{abstract}

Keywords: education system, professional standard, higher education, procurement specialist, vocational training, training program "Public procurement specialist".

\section{Introduction}

It is obvious that for a long time education has ceased to be a goal in itself and it has been demanded only by scientists striving for self-improvement and cognition of the unknown. Long

\footnotetext{
${ }^{*}$ Corresponding author

E-mail addresses: anna0710@yandex.ru (A.V. Popova)
} 
gone are the days when for most types of labor activities it was enough either to just start these activities, or to master the simplest skills by watching the masters. Today, in the overwhelming majority of cases, in order to engage in skilled labor, it is necessary to get relevant training. And when choosing this or that direction of training, we do not only assess ourselves (our capabilities) for the future profession, but also assess the demand for the future profession in the labor market in various spheres of the economy.

In education, as elsewhere in market conditions, the law of proportionality of supply and demand should function, that is, such educational conditions and opportunities should be created under which the demand of the national economy branches can, ideally, be fully satisfied. The objective of this research is to analyze professional training in the system of vocational secondary education and higher education in Russia, for such a specific, and at the same time, extremely important sphere, as the system of state (municipal) procurement, including training personnel for procurement activities of companies with state participation, state corporations, public companies, natural monopolies and organizations which are carrying out activities in the field of electricity, gas supply, heat supply, water supply, sewerage, wastewater treatment, solid waste management (Federal Law, 2011). In other words, for all those subjects of economic activity that are obliged to be guided when making purchases by Federal Law No. 44-FZ of April 5, 2013 "On the Contract System in the Field of Procurement of Goods, Works, Services for State and Municipal Needs" (hereinafter referred to as Federal Law No. 44-FZ) (Federal Law, 2011), and Federal Law No. 223-FZ of July 18, 2011 "On Procurement of Goods, Works, Services by Certain Types of Legal Entities" (hereinafter referred to as Federal Law No. 223 - FZ) (Federal Law, 2013).

The relevance of the chosen research topic is determined by the fact that the public procurement market is one of the most important elements of the country's socio-economic development, while the public procurement system is formed as the most significant institution of state regulation of the economy, affecting both its structure and development dynamics. From this point of view, public procurement can be considered as a financial instrument for the formation of state policy to perform a number of fundamental functions in different spheres, such as the social sphere, conservation of natural resources, food and energy security, etc. (Yuzvovich et al., 2019: 162). These circumstances actualize the need to create a separate sphere for training specialists both in secondary vocational educational institutions and in higher educational institutions of the Russian Federation.

\section{Materials and methods}

The paper hypothesizes that the public procurement market in the Russian Federation is not provided with the necessary multi-level training system for highly qualified specialists, as provided for by the professional standard "Public procurement specialist", and that the existing opportunities for obtaining only additional vocational training are clearly insufficient.

To test this hypothesis on the base of general philosophical methods of cognition, the authors of the article used the entire set of formal logical general scientific and private scientific research methods, as well as methods of expert assessments in combination with methods of specific sociological research.

Particular attention was paid to the method of specific sociological research, which made it possible to test the put-forward hypothesis, as well as to study the level and training direction of employees of procuring organizations and contract services, to identify their views on the knowledge and skills that they need in their work, the demand for basic specialized education, as well as attitude towards additional professional education.

Using the Google form service, we have compiled a questionnaire that includes 18 questions on the research topic. Due to the inaccessibility of respondents for the survey, the sample was selected using the "snow-ball" method, which refers to the sampling method without probability. The survey was started with a small number of respondents, and then the sample was expanded with the recommendations of the original interviewees regarding other potential respondents known to them. The survey involved 6o respondents from among employees of procuring organizations and contract services. They were divided in three interviewed groups headlined as specialists (in quantity of 21), managers (9) and the else (30). 


\section{Discussion}

Despite the relevance of the issue and the importance of public procurement for the economy as a whole, training specialists for procurement is not widely discussed in the scientific literature, however, a number of publications can be distinguished that investigate this problem through the prism of the requirements established by the professional standard "Public procurement specialist". O. V. Vorobyeva, Deputy Director of the Institute of Public Procurement, believes that the efficiency of business processes of the entire organization largely depends on the level of qualifications of employees of procurement departments (Vorobyeva, 2016). Belarusian researchers note the positive experience of the Russian Federation, in contrast to Belarus, which established in part 6 of Article 38 of Federal Law No. 44-FZ the provision that employees of the contract service and the contract manager must have a degree in higher education or additional vocational training in the field of procurement (Kovalinsky, Popov, 2018).

It should be noted that the direction of training in the higher education system of the Russian Federation in the field of procurement is not available, therefore "since January 1, 2017, training in additional education programs in accordance with the current legislation has become mandatory" (Kravchenko, 2018) for employees in the field of procurement. At the same time, it should be mentioned that some researchers believe that additional vocational training is quite enough to train a qualified employee in this area and achieve compliance with the requirements of a professional standard (Grigoriev, 2016). However, scientific articles have recently appeared in which the authors underline the need for training such specialists in certain areas of training. So, according to A.E. Metlina, "training in the profile "Public procurement specialist" is mostly justified in the system of higher education, the level of training is a master's degree (...) in the framework of two directions: "State and municipal administration" and "Vocational training (according to different branches of industry)". The importance of training in the framework of the direction "Vocational training (according to different branches of industry)" is associated with the need to form professional teaching staff, the need for which, as shown by the analysis of the demand, both by non-profit and by commercial organizations, is increasing" (Metlina, 2020: 158).

In this regard, it would be to the point to mention some views of the American specialists on the issue. Michael Linders indicates that voluntary certification systems and professional associations are important components of the system for assessing the quality of procurement services in developed countries (Linders, 2013: 21). The Institute for Supply Management (ISM) has been the main professional association in the United States since 1915. This association represents a network of more than 180 ISM-related educational and research organizations; it conducts seminars, conferences, and publishes its materials on procurement issues in scientific collections, monographs and periodicals. In the current century, training specialists in the field of public procurement is carried out in 70 educational organizations, including Harvard University, Federal Acquisition University, Defense Acquisition University, and Institute for Public Procurement and others (Public Procurement, 2019). The curriculum offered by the educational institutions provides training in both general and highly specialized issues, depending on the level of qualifications (availability of qualifications as such) of the student and his personal wishes. For example, the National Institute of Governmental Purchasing (NIGP) offers over 100 course options either online, including monthly virtual conferences, webinars, or scheduled traditional classroom and annual research conferences, and on-demand courses (at the request of the client) (Coursework, 2019).

However, you should not forget that in the countries of the European Union, the United States and Canada, unlike the Russian Federation, the state does not have a system of state accreditation of educational services and a system for their licensing. In these countries, the quality and high competitiveness of professional education is ensured by a rating system and certification. Thus, in the United States and Great Britain, public procurement specialists are trained by private licensed organizations that compete with each other in the provision of such educational services (Tsibikov, 2019: 17-19). In China, the leading organizational and methodological center for training and advanced training of public procurement specialists is the Public Procurement Sector of the Chinese Federation of Logistics and Procurement (CFLP) (Changzhou, 2019), as well as an extensive network of training centers. They offer training "from scratch" both in full-time form and in the form of online training. Structurally, the curriculum does not differ significantly from the training programs conducted in the United States and Great Britain (Tsibikov, 2019: 20-21; Notice of the start, 2018). 


\section{Results}

It should be noted that over 3 million people are engaged in procurement in Russia. As of December 1, 2020, 321,000 government customers and 87,000 organizations operating under Federal Law No. 223 were registered in the unified information system in the field of procurement, each of which employs from 10 to 200 people (Summary analytical report, 2020). And this is not to mention the tender specialists from the supplier's side. For comparison, according to the Union of Architects, the number of practicing architects in 2011 was about 16,000 people in Russia (there are no official statistics), and at the moment it is actually not growing, however, more than 50 universities and several secondary vocational educational institutions are training specialists in this profile (There are 16000..., 2011). We will touch upon the issue of training specialists for the contract system below.

It is clear that the key figure, although not the only one, in the field of procurement is a procurement specialist. Requirements for such employees, including educational criteria, are established by the Professional Standard "Public procurement specialist", approved by the order of the Ministry of Labor and Social Protection of the Russian Federation (September 10, 2015) (Professional standard, 2015). This standard establishes the requirements for the education of a procurement specialist and an employee of the contract service: 1) secondary vocational training; 2) additional vocational training - professional development and retraining programs in the field of procurement. However it is difficult to understand from the text of the professional standard whether it is necessary to meet either both requirements, or whether it is enough to choose one from them. For a senior procurement specialist, a procurement consultant, and a contract manager, it is mandatory to have bachelor's degree and additional vocational education (advanced training programs and retraining programs in the field of procurement). For leading specialists, deputy heads of divisions, heads of divisions, managers of contract service and advisers, it is obligatory to be a specialist or to have a master's degree, and, besides, to have additional vocational training in the field of procurement.

What specific direction of training the corresponding level should be for an employee, the Professional Standard "Public procurement specialist" (like most standards) does not indicate. Based on the necessary functions for a procurement specialist, set out in the standard, it can be concluded that, in addition to special knowledge and skills in the contractual sphere, he will need knowledge in the field of jurisprudence, accounting, economics, statistics, marketing, IT technologies, etc.

Obviously, such set of knowledge and skills does not offer any direction of training, and none of Federal State Educational Standards (FSES) includes, and there is no special educational standard for specialists in the field of procurement, that is, specialists for the contract system are not trained by any university or secondary specialized educational institution. The group of professions united by the Professional Standard "Public procurement specialist" is indicated, there is a demand, confirmed by more than 3 million employees, but it is not yet possible to obtain the relevant specialized education.

We believe that this situation does not fully meet the needs of the national economy. An imbalance between supply and demand is created, in which tens of thousands of professionals are trained by dozens of educational institutions, and in a profession represented by millions of employees, training as a basic, rather than additional education, is not carried out by any educational institution.

Perhaps, including this, lies the low efficiency of spending budget funds at all levels of government, a significant part of which is spent just on the so-called "contracted expenses". So, as of January 1, 2021, the limit of budgetary obligations for 2020 for contractual expenses, that is, expenses under government contracts for the procurement of goods, works and services for government needs, including budget investments, as well as subsidies for capital investments to budgetary and autonomous institutions, other legal entities and subsidies for co-financing capital investments in state (municipal) property were approved in the amount of 2,711.6 billion rubles (open part), in 2019-2,541.4 billion rubles. At the same time, in 2020, the Accounts Chamber of the Russian Federation identified 3,698 violations totaling 355.5 billion rubles. The largest share of violations falls on violations in public procurement and procurement by certain types of legal entities, that is, violations within the framework of the implementation of Federal Laws of April 5, 2013 No. 44-FZ "On the contract system in the field of procurement of goods, works, services for the 
provision of state and municipal needs" and dated July 18, 2011 No. 223-FZ "On the procurement of goods, works, services by certain types of legal entities" (Analytical note, 2020).

Obviously, all the failures of the contract system cannot be attributed to the lack of special training for its employees, but nevertheless, we believe that the opportunity to receive such training would only benefit the procurement sector. Therefore, in order to determine the demand for this kind of basic education among employees in the particular sphere and to identify possible approaches to the formation of an appropriate educational standard, we considered it necessary to conduct a study that would give an idea of the level, direction of education and other related characteristics of the current representatives of the contract system, as well as their relation to the basic education in procurement.

To provide a careful research on the issue we compiled an anonymous questionnaire that included 18 questions on the need for special education for employees of procuring organizations and procurement specialists. Due to the specifics of the respondents' activities and their inaccessibility, the "snow-ball" method was chosen for the survey (Jablonska, 2013), since it is used precisely when it is difficult to find representatives of the target group by other methods, the availability of respondents is limited and they can only be accessed through trusted persons. As a result, 60 respondents from among employees of procuring organizations and contract services took part in the survey. Among those surveyed $35 \%$ of respondents were purchasing employees (procurement specialists and experts), $15 \%$ - heads of departments in purchasing organizations, $17 \%$ - procurement lawyers, $22 \%$ - employees of economic security departments, and $8 \%-$ marketers; the remaining $3 \%$ included economists and insurers. With regard to gender distribution, it is interesting to mention that in this area there is a clear prevalence of male employees, and they turned out to be $70 \%$. All respondents at the time of the survey had at least one year of experience in the field of procurement, of which: $18 \%$ - more than 10 years, $45 \%-$ 6-10 years, and $37 \%$ - from 1 to 5 years.

It is significant that only $17 \%$ of respondents indicated that procurement is their first field of activity, while the overwhelming majority of respondents said that they had previously engaged in other types of activity, and the range of previous professions turned out to be very diverse. The results of answers to the question "If you were previously engaged in another type of activity, indicate which one" are presented below (Figure 1).

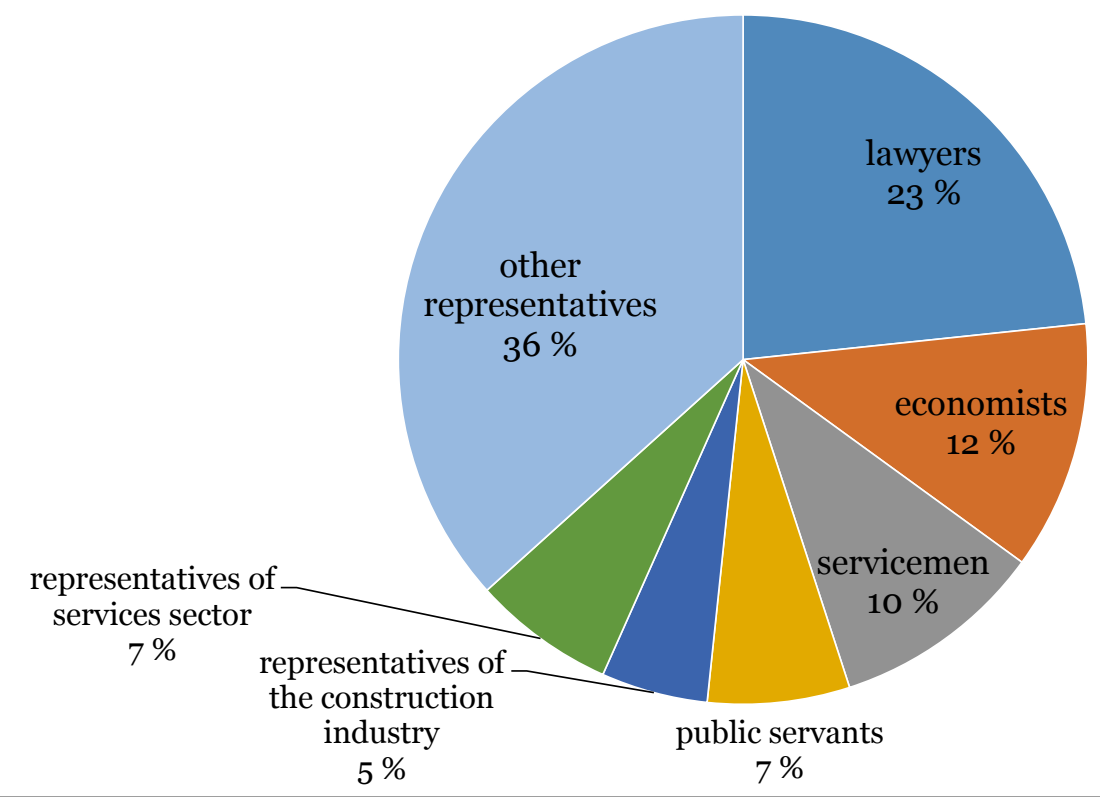

Fig. 1. The results of the answers to the question: "If you were previously engaged in another type of activity, indicate which one” 
The value of the Pearson's chi-square test is 25.961 at degree of freedom 12. At a significance level of $\mathrm{p}=0.05$, the critical value of $\chi_{2}$ is 21.026. The relationship between factorial and performance characteristics is statistically significant. For this figure data was reunited in three groups headlined as specialists (in quantity of 21), managers (9) and the else (30).

It can be seen from the diagram: $23 \%$ of respondents were previously employed in the legal sphere, $12 \%$ - in the economic sphere, $10 \%$ - were military personnel, $7 \%$ - civil servants, the same amount ( $7 \%$ ) worked in the service sector before procurement, $5 \%$ of respondents were engaged in construction; the remaining $36 \%$ - former power engineering employees, engineers, technicians, law enforcement officers, and the representatives of trade, production of goods, supplies, financiers, etc.

At the same time, it is also indicative to illustrate the rather unreliable interaction of the labor market with the field of educational services: when answering the question "What is the direction of your education?" (Figure 2), $35 \%$ of respondents indicated as such - jurisprudence, $32 \%$ engineering, $11 \%$ - management, $10 \%$ - economics. The remaining $12 \%$ of respondents were employees who received education in such areas of training as: power engineering, military affairs, economics and jurisprudence, trading business, pedagogy, international relationships, and public administration.

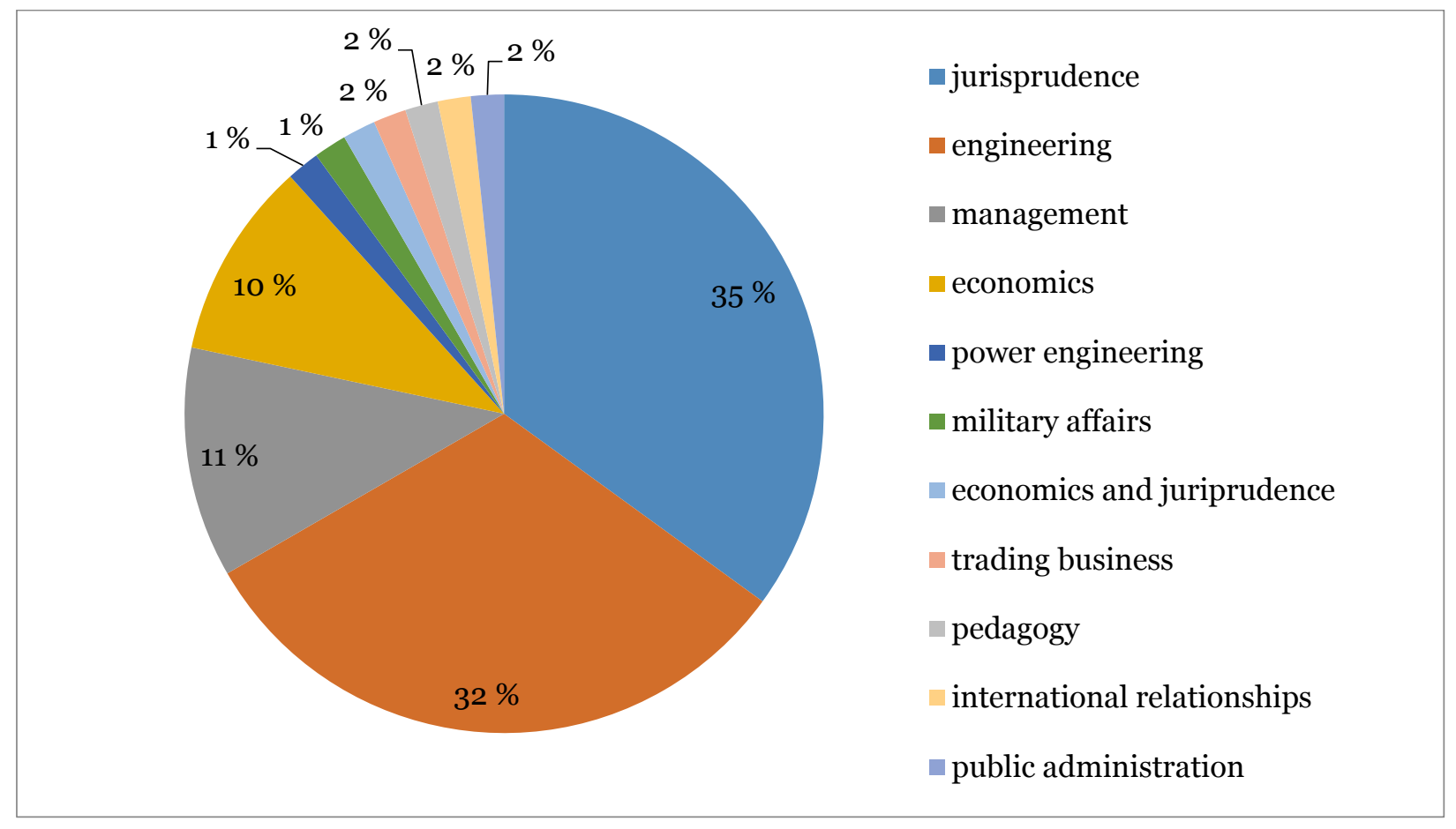

Fig. 2. The results of the answers to the question: "What is the direction of your education?"

The value of the Pearson's chi-square test is 19.434 at degree of freedom 8 . At a significance level of $\mathrm{p}=0.05$, the critical value of $\chi_{2}$ is 15.507 . The relationship between factorial and performance characteristics is statistically significant. For this figure data was reunited in three groups headlined as specialists (in quantity of 21), managers (9) and the else (30).

Analyzing the results obtained, let's take lawyers: $35 \%$ of respondents received legal education, while only $23 \%$ of respondents were previously engaged in legal activities; in the procurement sector, only $17 \%$ of respondents have identified themselves as lawyers. The situation with engineers and other technical specialists is even more indicative: $32 \%$ of the respondents received a technical education, previously worked in their specialty less than $4 \%$, within the framework of this survey, no one declared himself as an engineer or a technical specialist. This situation suggests that the very principle of choosing a place of work and profession is not based on previous education in many cases, but in the situation with engineers - in most cases. 
This devalues the very idea of specialized vocational education, reducing everything to the presence of a diploma confirming the receipt of the required level (secondary vocational education, higher education: degrees of bachelor, specialist or master). This fact finds its confirmation in a number of professional standards approved by the state, indicating the required level of education, but not its direction. And the level of education in these standards is sometimes clearly underestimated. So, as noted earlier, for a procurement specialist, the relevant professional standard sets the requirement for secondary specialized education and/or additional vocational training in the field of procurement.

What is the real situation in terms of the level of education among the interviewed employees of procuring organizations and contract services? The overwhelming majority of respondents have higher education, of which $61 \%$ are specialists, $21 \%$ have master's degree, $16 \%$ have bachelor's degree; one respondent has an academic degree and one has a secondary vocational training (Figure 3).

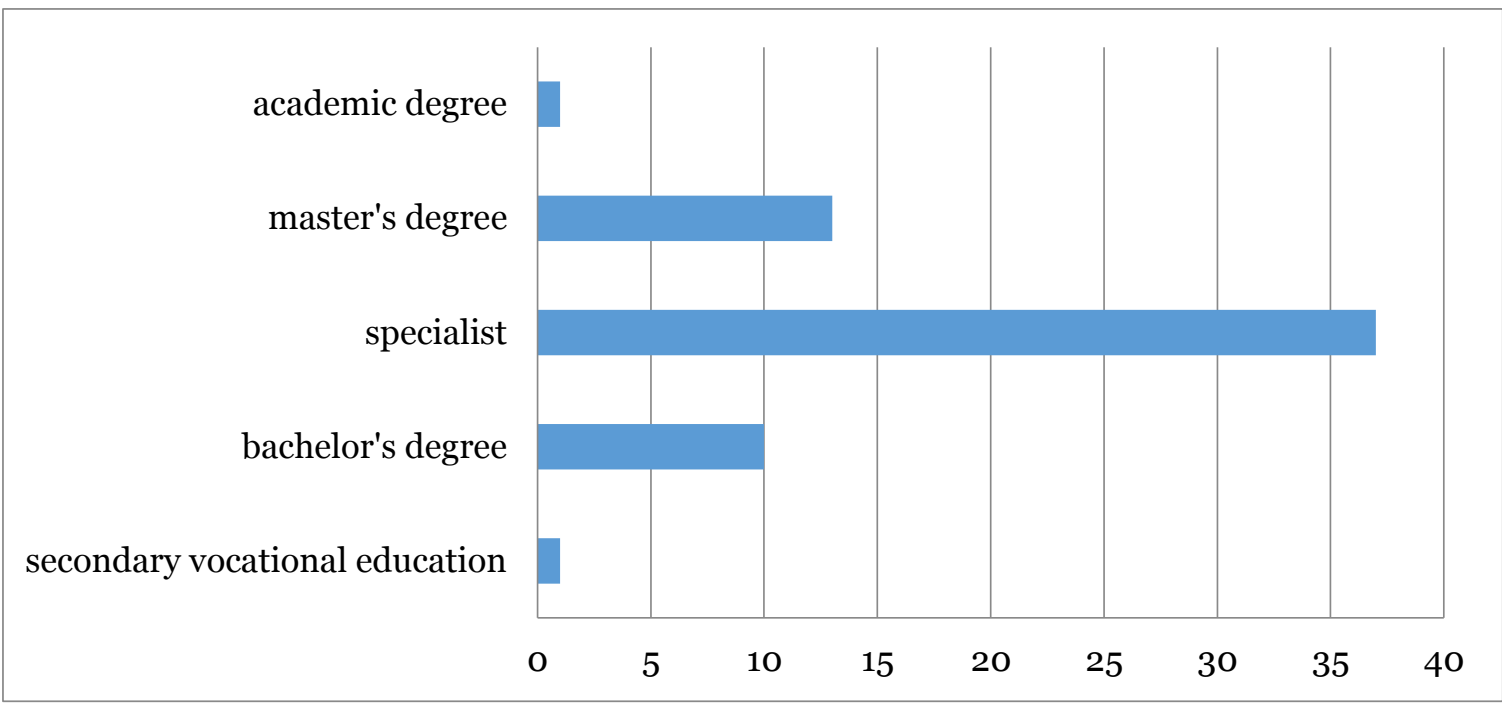

Fig. 3. The results of the answers to the question: "What is the level of your education?"

The value of the Pearson's chi-square test is 15.950 at degree of freedom 8 . At a significance level of $\mathrm{p}=0.05$, the critical value of $\chi_{2}$ is 15.507 . The relationship between factorial and performance characteristics is statistically significant. For this figure data was reunited in three groups headlined as specialists (in quantity of 21), managers (9) and the else (30).

On the one hand, this may indicate that in Russia, the majority of the population generally gives preference to higher education, not considering secondary vocational education sufficient for successful employment. On the other hand, this also testifies to the fact that the employer, especially the employer associated with the state, does not have a great desire to entrust the preparation and procurement of goods and services for state needs to persons without higher education. In this context, it should be noted that it is important for the state to decide: either indicate a higher required level of education for purchasing primary-level employees, or stop discriminating against citizens who have received secondary vocational education, providing them with preliminary vocational training in the relevant direction. However, for this, it is first necessary to create such a direction of vocational training, which would correspond to the demands of the market of state (municipal) contracts.

In this regard, one of the most important questions in the questionnaire was the question: "What kind of knowledge is in demand in procurement?" (Figure 4). In this case, the respondents were asked to choose several answer options, or to offer their own. 


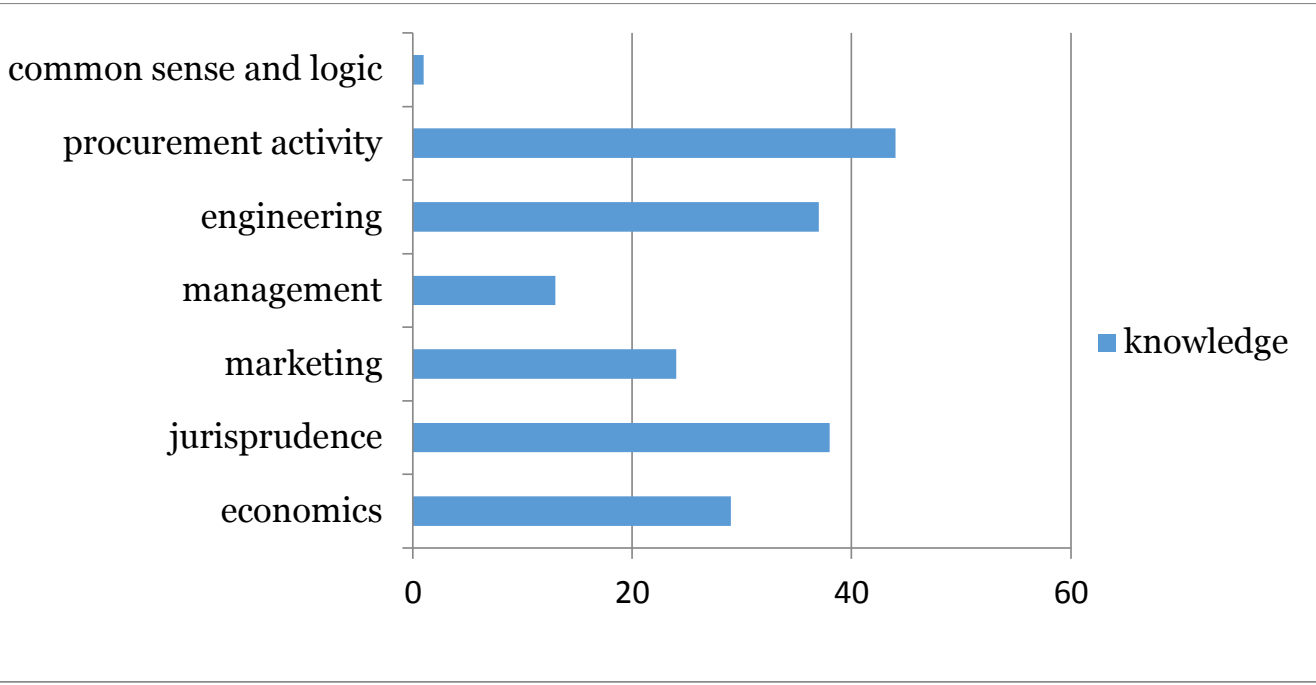

Fig. 4. The results of the answers to the question: "What kind of knowledge is in demand in procurement?"

The value of the Pearson's chi-square test is 80.895 at degree of freedom 12. At a significance level of $p=0.05$, the critical value of $\chi_{2}$ is 21.026. The relationship between factorial and performance characteristics is statistically significant. For this figure data was reunited in three groups headlined as specialists (in quantity of 21), managers (9) and the else (30).

As you can see from the diagram, $73 \%$ of the surveyed respondents believe that the most important knowledge is specialized knowledge of procurement. At the same time, answering the following question "When receiving basic education, did you study the organizational and legal aspects of procurement within the framework of any discipline?" the same number of respondents (73 \%) answered negatively (Figure 5).

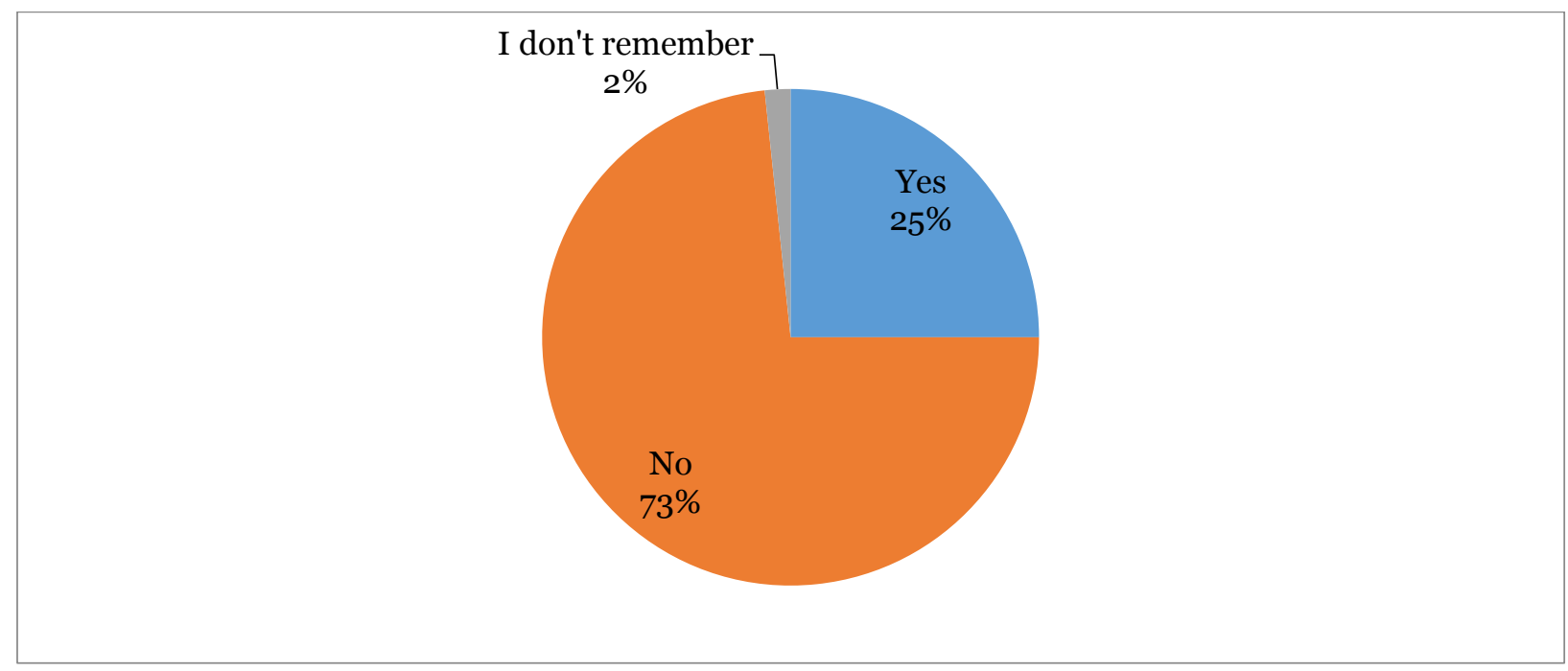

Fig. 5. The results of the answers to the question: "When receiving basic education, did you study the organizational and legal aspects of procurement within the framework of any discipline?"

The value of the Pearson's chi-square test is 7.463 at degree of freedom 2. At a significance level of $\mathrm{p}=0.05$, the critical value of $\chi^{2}$ is 5.991. The relationship between factorial and performance characteristics is statistically significant.

At the same time, although the majority of respondents (63\%) received their basic higher education more than 10 years ago, when asked whether it helped them in their work, they answered in 
the affirmative. Another $43 \%$ of respondents believe that education helped only partially, and $13 \%$ of respondents indicated that education did not help, and they had to master everything in practice.

In addition, the majority of interviewees $(80 \%)$ indicated that they have received additional vocational training in recent years - advanced training programs/or professional retraining programs in the field of procurement. However, the assessment of the benefits of this retraining was controversial (Figure 6).

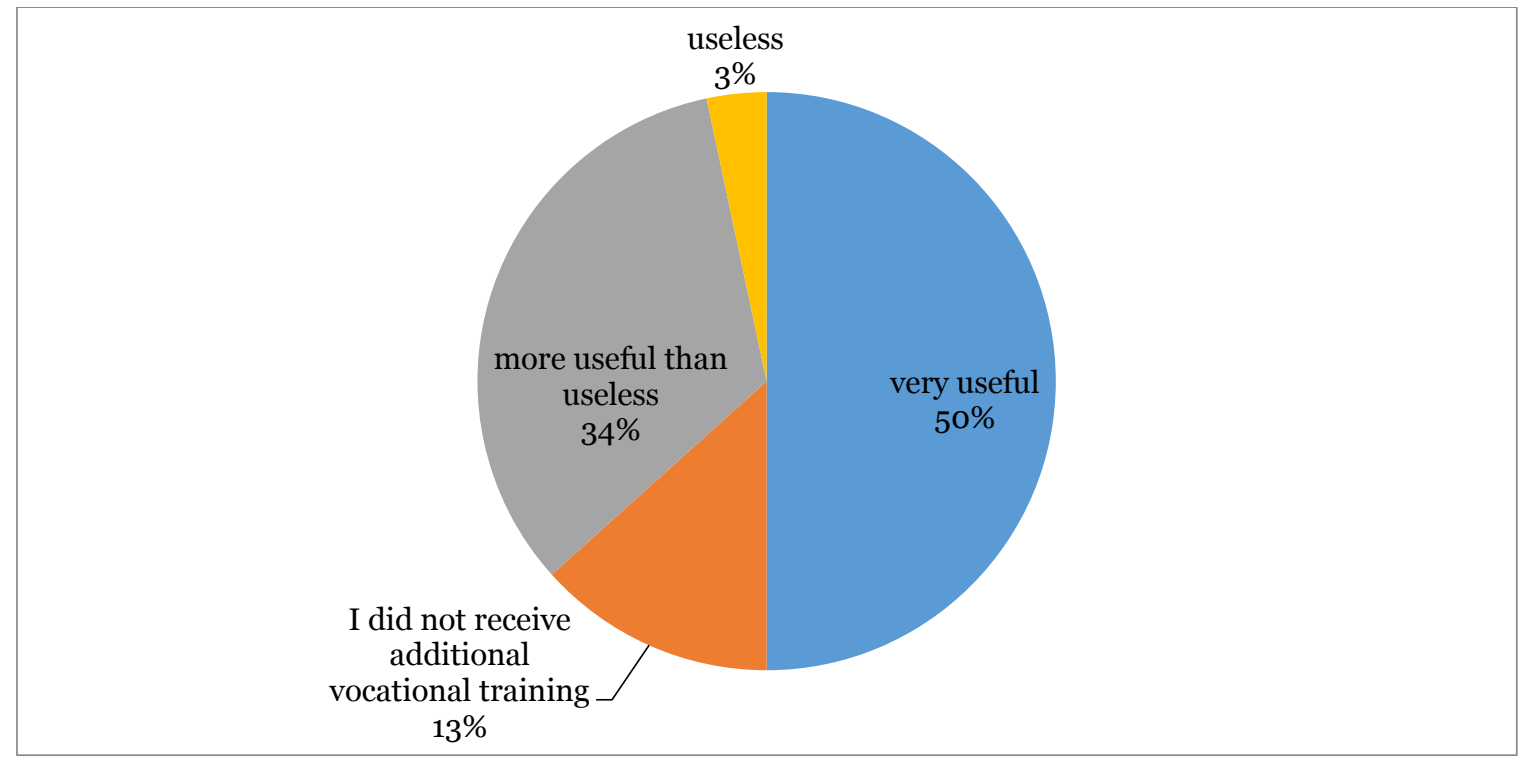

Fig. 6. The results of the answers to the question: "How useful was the additional vocational training for your professional activity?”

The value of the Pearson's chi-square test is 14.086 at degree of freedom 6. At a significance level of $\mathrm{p}=0.05$, the critical value of $\chi_{2}$ is 12.592. The relationship between factorial and performance characteristics is statistically significant. For this figure data was reunited in three groups headlined as specialists (in quantity of 21), managers (9) and the else (30).

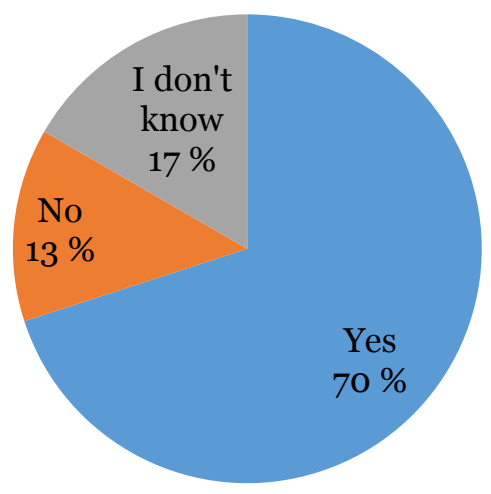

Fig. 7. The results of the answers to the question: "If time and work schedule allowed, theoretically, would you like to get a specialized higher education in the field of procurement?"

Thus, $50 \%$ of the respondents assessed additional vocational training as very useful, $34 \%$ of respondents chose the answer option: "more useful than useless", $3 \%$ of respondents considered it useless, and $13 \%$ of respondents could not evaluate the benefits of additional vocational training, since they did not receive it at all. Nevertheless, the analysis of the answers shows that the majority 
of respondents still see some degree of benefit in obtaining additional vocational training, even taking into account the fact that the majority of respondents have significant experience (45\% from 6 to 10 years, $18 \%$ - more 10 years) of work in the field of procurement, that is, they are interested in obtaining new special knowledge.

This conclusion is confirmed by the fact that, answering the question: "If time and work schedule allowed, theoretically, would you like to get a specialized higher education in the field of procurement?" (Figure 7), $70 \%$ of the interviewed respondents answered in the affirmative.

The value of the Pearson's chi-square test is 10.225 at degree of freedom 4. At a significance level of $\mathrm{p}=0.05$, the critical value of $\chi 2$ is 9.488. The relationship between factorial and performance characteristics is statistically significant. For this figure data was reunited in three groups headlined as specialists (in quantity of 21), managers (9) and the else (30).

Indicative for our research is the result of the answer to the question: Is there an opportunity in Russia to get a secondary vocational education or higher education in the direction of training "Public procurement specialist"? (Figure 8).

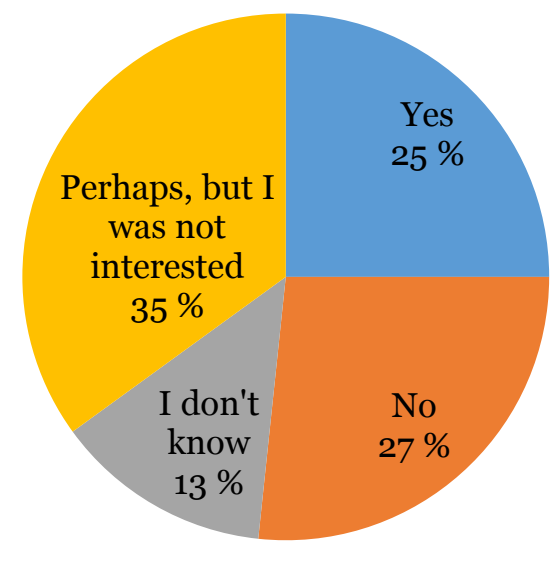

Fig. 8. The results of the answers to the question: Is there an opportunity in Russia to get a secondary vocational education or higher education in the direction of training "Procurement specialist?"

The value of the Pearson's chi-square test is 15.511 at degree of freedom 6 . At a significance level of $p=0.05$, the critical value of $\chi^{2}$ is 12.592 . The relationship between factorial and performance characteristics is statistically significant. For this figure data was reunited in three groups headlined as specialists (in quantity of 21), managers (9) and the else (30).

Even taking into account that for the overwhelming majority of survey participants, the problem of obtaining higher, and secondary vocational education is no longer relevant (63\% aged 31 to $40,17 \%$ - from 41 to 50 years old, $3 \%$ - over 50 ), an interesting fact is that $25 \%$ of respondents are sure that the possibility of obtaining such an education exists, $35 \%$ are not sure about this, but they assume such an opportunity; and only $27 \%$ know that it is impossible to get such an education in Russia. Probably, this figure correlates in a certain way with the number of younger survey participants (13\% - aged 26 to 30, $3 \%$ - under 25 ) who could be interested in the possibility of obtaining a specialized education and realized that it was not available.

\section{Conclusion}

As a result of the study, the following key conclusions were made. Currently in Russia there is a professional standard "Public procurement specialist", which establishes the requirements for the level of education of this group of employees, not lower than secondary vocational training. Analysis of labor functions, knowledge and skills of the employee, allows us to conclude that he must have a whole range of knowledge in the field of jurisprudence, economics, marketing, etc. In the Russian Federation there is no such training area as "Public procurement specialist" or 
"Tender Specialist", there is only an opportunity to get additional vocational education, usually in the form of short-term refresher courses, but not all respondents equally positively assess their usefulness (50 \% of respondents).

Currently, there are several million employees in the procurement sector, and the data from the study shows that they are in demand for specialized education in the procurement sector $70 \%$ of respondents answered that, if possible, they would like to receive a specialized basic education in procurement. In addition, $73 \%$ of the surveyed respondents believe that the most important in their work is specialized knowledge of procurement. At the same time, as shown by the survey data, the same $73 \%$ of respondents indicated that when receiving basic education, they did not study the organizational and legal aspects of procurement, either separately or within the framework of any academic discipline.

In such a situation, the employer is, in fact, forced to introduce a mentoring system in their organization, in which more experienced workers must first train newcomers before they can start work. Moreover, despite the rather long experience in procurement among the majority of respondents $(18 \%$ - have been working in the industry for more than 10 years, $45 \%$ - from 6 to 10 years), only $43 \%$ of the respondents consider themselves to be highly qualified specialists in the procurement sector. This may indicate, among other things, that having not received a systemic education, and trained in such a "handicraft" way, these people simply experience a certain "complex" of lack of the required education.

However, no matter how important special knowledge is, the respondents noted that in order to improve their professionalism in the field of procurement, they would also like to acquire legal knowledge (45 \%), technical knowledge (43\%), managerial knowledge and skills (43\%), economic knowledge and skills (32\%), marketing knowledge and skills (28\%), as well as additional knowledge in the field of IT technologies (25\%). Obviously, such needs can by no means be satisfied by obtaining additional vocational education.

The above analysis results show that, of course, at present there is an urgent need to create a new direction of training for the millionth army of future employees of purchasing organizations, contract services, as well as tender specialists from suppliers who will replace the current ones. Moreover, we believe that if the Professional Standard "Public procurement specialist" implies, on an equal basis with higher and secondary specialized education for purchasing first-level employees, it should be possible to obtain both of these levels as the basic education offered by higher and secondary specialized educational institutions.

\section{References}

Analytical note, 2020 - Analytical note on the implementation of the federal budget and the budgets of state extra-budgetary funds of the Russian Federation for January - December (2020). [Electronic resource]. URL: https://ach.gov.ru/audit/_operative\%20doclad\%20yanvar-December \%202020.zip/Operational\%20document\%20yanvar-December\%202020/o.\%20analytic al\%20recording\%20FB+FIU+FSS+FOMS.pdf (date of access: 09.06.2021). [in Russian]

Changzhou, 2019 - Changzhou: conduct annual training of experts on public procurement evaluation in 2018. [Electronic resource]. URL: http://www. ggzy.gov.cn/info/localns/201901/25/content_45f292f782f24139b1783689823bf8da.shtml (date of access: 29.06.2021).

Coursework, 2019 - Coursework (2019). [Electronic resource]. URL: https://www.nigp.org/ home/your-learning-journey/education/take-a-course (date of access: 29.06.2021)

Federal Law, 2011 - Federal Law. No 223-FZ of July 18 "On Procurement of Goods, Works, Services by Certain Types of Legal Entities". Sobranie zakonodatel'stva Rossijskoj Federacii. 2011. N 30 (Chast' I). St. 4571. [in Russian]

Federal Law, 2013 - Federal Law (2013). No 44-FZ «On the contract system in the field of procurement of goods, works, services for state and municipal needs». Sobranie zakonodatel'stva Rossijskoj Federacii. 2013. No. 14. St. 1652. [in Russian]

Grigoriev, 2016 - Grigoriev, N.S. (2016). Additional education for achieving the qualification requirements of the professional standard "specialist in the field of procurement". Aktual'nye problemy gumanitarnyh i estestvennyh nauk. 6-3: 25-28. [in Russian]

Jablonska, Sobieraj, 2013 - Jablonska, K., Sobieraj, A. (2013). Sampling Methodology in Social Sciences. Bezpieczenstwo i Technika Pozarnicza. 32: 31-36. 
Kovalinsky, Popov, 2018 - Kovalinsky, A.I., Popov, A.A. (2018). Training and certification of specialists in the field of public procurement. V sbornike: Aktual'nye problemy biznesobrazovaniya. Materialy XVII Mezhdunarodnoj nauchno-prakticheskoj konferencii. Belgorodskij gos. universitet, Iniversitet biznesa i menedzhmenta tekhnologij, Associaciya biznes-obrazovaniya; [redkol.: V. V. Apanasovich (gl. red.) i dr.]. Minsk : Nacional'naya biblioteka Belarusi: 84-89. [in Russian]

Kravchenko, 2018 - Kravchenko, I.A. (2018). The role of professional development of specialists in the field of state (municipal) procurement. Nauchno-metodicheskoe obespechenie ocenki kachestva obrazovaniya. 1(4): 149-152. [in Russian]

Linders, 2013 - Linders, M. (2013). Procurement and supply management: textbook for students of higher educational institutions studying in the specialties of economics and management (080100), "Commerce" (080300), "Logistics" (o80506). Michael Linders [et al.]; translated from English. Edited by Yu. A. Shcherbanin. 13th ed. Moscow: JUNITI. [in Russian]

Metlina, 2020 - Metlina, A.E. (2020). Professional training and training of a specialist in the field of public procurement. Vestnik TGPU. 6(212): 158-166. DOI: 10.23951/1609-624X-2020-6158-166 [in Russian]

Notice of the start, 2018 - Notice of the start of the online training "Lecture hall for bidding and procurement”. Public bidding service platform in China. [Electronic resource]. URL: http://www.ceb pubservice.com/monitorindustry/monitorplat/2017/12/9600.shtml (date of access: 29.01.2021).

Professional standard, 2015 - Professional standard (2015) "Specialist v sfere zakupok" [Electronic resource]. URL: https://goszakaz.ranepa.ru/files/prof_stand.pdf (date of access: 19.06.2021) [in Russian]

Public Procurement, 2019 - Public Procurement in Higher Education. [Electronic resource]. URL: https://www.nigp.org/home/your-learning-journey/education/higher-education-procurement (date of access: 18.06.2021).

Summary analytical report, 2020 - Summary analytical report on the results of monitoring purchases, goods, services for state and Municipal needs in accordance with Federal Law No. 44FZ of 05.04.2013 "On the contract system in the field of procurement of Goods, Works, services for State and Municipal needs" by the end of 2020. [Electronic resource]. URL: https://minfin.gov.ru/ common/upload/library/2021/05/main/44-FZ.pdf (date of access: 19.06.2021) [in Russian]

There are $16000 . . ., 2011$ - There are 16 thousand practicing architects in Russia Available at: https://russkiymir.ru/news/27199/ (date of access: 28.06.2021). [in Russian]

Tsibikov, 2019 - Tsibikov, V.A. (2019). About the foreign experience of training specialists in public procurement on the example of the USA, Great Britain and China. Upravlenie. 4: 16-23. DOI 10.26425/2309-3633-2019-4-16-23 [in Russian]

Vorobyeva, 2016 - Vorobyeva, O.M. (2016). Qualification of employees of procurement departments in connection with the entry into force of the professional standard "specialist in the field of procurement". V sbornike: IV Vserossijskaya prakticheskaya konferenciya-seminar "Korporativnye zakupki - 2016: praktika primeneniya Federal'nogo zakona № 223-FZ": 6-15. [Electronic resource]. URL: https://gkgosz.sakha.gov.ru/news/front/view/id/2806022 (date of access: 27.06.2021). [in Russian]

Yuzvovich et al., 2019 - Yuzvovich, L.I., Isakova, N.Y., Istomina, Y.V. (2019). The system of public procurement: theoretical and practical aspects: monograph. Ekaterinburg: Izdatel'stvo Ural'skogo universiteta. [in Russian] 